\title{
Characteristic of intoxicated cyclists compared to sober cyclists admitted to a London Major Trauma Centre
}

\author{
Anna E Forbes*, John M Schutzer-Weissmann, Alex Wang, Matthew Wordsworth, Mark H Wilson \\ From London Trauma Conference 2014 \\ London, UK. 9-12 December 2014
}

\section{Background}

Studies have suggested that alcohol is an independent risk factor for cycling accidents [1].

This study aimed to compare mechanisms of injury, injury patterns and helmet use in intoxicated and sober cyclists.

\section{Methods}

Cyclists admitted to a London Major Trauma Centre were identified from Emergency Department Records, the Trauma audit and research network, Major Trauma Ward Lists and intensive care admission documents.

Admission toxicology and prehospital and emergency department documentation were analysed to identify patients who had negative alcohol tests and those who had elevated blood alcohol levels or a history of recent alcohol ingestion. Lack of a history of alcohol use was not used to identify sober cyclists. These patient groups were then analysed to assess helmet use and injury pattern.

\section{Results}

Initially 186 cyclists were identified (152 males and 28 females) and of these 80 had alcohol levels or positive history recorded. Of the 186 cyclists $10 \%$ of female cyclists were intoxicated compared to $20 \%$ of males. In the intoxicated group $(\mathrm{n}=32)$ fall was the most common mechanism of injury $(53 \%)$ whereas in the sober group $(n=46)$ collision with a car was the most common (52\%). In those for whom helmet wearing data was available (17 intoxicated, 36 sober) $82 \%$ of drunk cyclists weren't wearing a helmet compared to $55 \%$ of sober cyclists. Injury patterns were similar in both drunk and sober groups.

\footnotetext{
* Correspondence: aeaforbes@gmail.com

Intensive Care Unit and Major Trauma Ward, St Mary's Hospital, Imperial College Healthcare NHS Trust, London, UK
}

\section{Discussion}

This study was limited by the lack of toxicology data available. However it showed that intoxication was present in at least $18 \%$ of those admitted to a major trauma centre following cycling accidents. It was also identified that intoxicated cyclists were less likely to protect themselves with a helmet and in contrast to sober cyclists were less likely to have accidents involving other road users.

\section{Published: 11 September 2015}

\section{Reference}

1. Crocker P, Zad O, Milling T, et al: Alcohol, bicycling and head and brain injury: a study of impaired cyclists riding patterns. Amer J Emerg Med 2010, 28:68-72.

doi:10.1186/1757-7241-23-S2-04

Cite this article as: Forbes et al:: Characteristic of intoxicated cyclists compared to sober cyclists admitted to a London Major Trauma Centre. Scandinavian Journal of Trauma, Resuscitation and Emergency Medicine 2015 23(Suppl 2):O4.

\section{Submit your next manuscript to BioMed Central and take full advantage of: \\ - Convenient online submission \\ - Thorough peer review \\ - No space constraints or color figure charges \\ - Immediate publication on acceptance \\ - Inclusion in PubMed, CAS, Scopus and Google Scholar \\ - Research which is freely available for redistribution \\ Submit your manuscript at www.biomedcentral.com/submit}

